Bryn Mawr College

Scholarship, Research, and Creative Work at Bryn Mawr

College

Education Program Faculty Research and

Scholarship

Education Program

2019

\title{
Toward theories of partnership praxis: an analysis of interpretive framing in literature on students as partners in teaching and learning
}

Kelly E. Matthews

Alison Cook-Sather

Bryn Mawr College, acooksat@brynmawr.edu

Anita Acai

Sam Lucie Dvorakova

Peter Felten

See next page for additional authors

Let us know how access to this document benefits you.

Follow this and additional works at: https://repository.brynmawr.edu/edu_pubs

Part of the Education Commons

\section{Custom Citation}

Matthews, Kelly, Alison Cook-Sather, Anita Acai, Sam Lucie Dvorakova, Peter Felten, Elizabeth Marquis, Lucy Mercer-Mapstone. 2019. "Toward theories of partnership praxis: an analysis of interpretive framing in literature on students as partners in teaching and learning." Higher Education Research \& Development 38.2: 280-293.

This paper is posted at Scholarship, Research, and Creative Work at Bryn Mawr College. https://repository.brynmawr.edu/edu_pubs/40

For more information, please contact repository@brynmawr.edu. 
Authors

Kelly E. Matthews, Alison Cook-Sather, Anita Acai, Sam Lucie Dvorakova, Peter Felten, Elizabeth Marquis, and Lucy Mercer-Mapstone 


\section{Toward Theories of Partnership Praxis: An Analysis of Interpretive}

Framing in Literature on Students as Partners in Teaching and Learning

Kelly E Matthews ${ }^{\mathrm{a}^{*}}$, Alison Cook-Sather ${ }^{\mathrm{b}}$, Anita Acai ${ }^{\mathrm{c}, \mathrm{d}}$, Sam Lucie

Dvorakova $^{\mathrm{a}, \mathrm{e}}$, Peter Felten ${ }^{\mathrm{f}}$, Elizabeth Marquis ${ }^{\mathrm{d}}$, and Lucy Mercer-Mapstone ${ }^{\mathrm{a}}$

${ }^{a}$ Institute for Teaching \& Learning Innovation, University of Queensland, Brisbane,

Queensland, Australia

${ }^{b}$ Bryn Mawr College, Bryn Mawr, Pennsylvania, United States of America

${ }^{c}$ Department of Psychology, Neuroscience, \& Behaviour and Office of Education Science, Department of Surgery, McMaster University, Hamilton, Ontario, Canada

${ }^{d}$ MacPherson Institute, McMaster University. Hamilton, Ontario, Canada

${ }^{e}$ University of Edinburgh, Edinburgh, Scotland, United Kingdom

${ }^{f}$ Elon University, Elon, North Carolina, United States of America

*Corresponding author: k.matthews1@uq.edu.au

\section{Word Count 6820}




\title{
Toward Theories of Partnership Praxis: An Analysis of Interpretive Framing in Literature on Students as Partners in Teaching and Learning
}

\begin{abstract}
A body of literature on students as partners $(\mathrm{SaP})$ in higher education has emerged over the last decade that documents, shares, and evaluates $\mathrm{SaP}$ approaches. As is typical in emerging fields of inquiry, scholars differ regarding how they see the relationship between the developments in SaP practices and the theoretical explanations that guide, illuminate, and situate such practices. In this article we explore the relationship between theory and practice in $\mathrm{SaP}$ work through an analysis of interpretive framing employed in scholarship of $\mathrm{SaP}$ in teaching and learning in higher education. Through a conceptual review of selected publications, we describe three ways of framing partnership that represent distinct but related analytical approaches: building on concepts; drawing on constructs; and imagining through metaphors. We both affirm the expansive and creative theorising in scholarship of SaP in university teaching and learning and encourage further deliberate use and thoughtful development of interpretive framings that take seriously the disruptive ethos and messy human relational processes of partnership. We argue that these developmental processes move us toward formulating theories of partnership praxis.
\end{abstract}

Keywords: students as partners, student-staff partnerships, theory, theorising, construct, metaphor

\section{Introduction}

Over the last decade, a rapidly expanding body of literature on students as partners $(\mathrm{SaP})$ in higher education has emerged to document, share, and evaluate $\mathrm{SaP}$ practices. The variation in this literature regarding how scholars make sense of partnership approaches is characterised by some as a lagging of theoretical arguments behind developments in practice in our field (Peters, 2016; Seale, Gibson, Haynes, \& Potter, 2015). We agree that, “"without [good, explicit] theory, experience has no meaning... one has no questions to ask. Hence, without theory, there is no learning"' (Deming, 1993, p. 105, quoted in Trowler, 2012, p. 276). However, we see the range of interpretive framing in literature on $\mathrm{SaP}$ in university teaching 
and learning as reflective of an exciting evolution, rather than an absence, of ways to theorise practice. We see in the literature an expansion of focus from the almost purely practical to include increased attention to theorised practice. In other words, we see a process of theoretical development concomitant with an emerging field, and we seek to contribute to the movement toward formulating theories of partnership praxis.

In this article, we explore the evolving relationship between theory and practice in $\mathrm{SaP}$ through describing how selected works employ various interpretive approaches to analysing pedagogical partnership. We begin with an overview of $\mathrm{SaP}$ as a rapidly expanding phenomenon, followed by an explanation of our focus on the process of theorising rather than the presentation of theories. Next, we offer a rationale for the usefulness of three forms of theorising in SaP scholarship that we gather under the umbrella of interpretive framing: building on concepts; drawing on constructs; and imagining through metaphors. We then present a thematic analysis of how these interpretive framings are employed in the literature. We conclude with a discussion of the significance of our findings, an affirmation of expansive, creative, and imaginative theorising in scholarship of SaP, and an encouragement of further deliberate use and thoughtful development of interpretive framings that take seriously the disruptive ethos and messy human relational processes of partnership praxis that speak to both researchers and practitioners.

\section{Students as Partners in Higher Education}

$\mathrm{SaP}$ represents an array of practices and possibilities through which students collaborate with faculty/academics or staff and also other students in teaching and learning activities (Bovill, 2017; Healey, Flint, \& Harrington, 2014). A widely cited definition of partnership is 'a collaborative, reciprocal process through which all participants have the opportunity to contribute equally, although not necessarily in the same ways, to curricular or pedagogical 
conceptualization, decision making, implementation, investigation, or analysis' (Cook-Sather, Bovill, \& Felten, 2014, pp. 6-7). Informing immediate practice and perpetual aspiration, 'students as partners' in higher education 'challenges traditional assumptions about the identities of, and relationships between, learners and teachers' and explicitly names students 'to intentionally and clearly assert the role students can assume alongside others with educational expertise' (Matthews, 2017, p. 1).

$\mathrm{SaP}$ in higher education can be traced to historical commitments arising from the 'student voice' movement of the 1990s in the school sector, which was rooted in social justice and democratic ideologies (Cook-Sather, in press), and has threads extending from critical theories (Bovill, 2013). Scholars have characterised the emergence of pedagogical partnership as a reaction to the increasingly neoliberal forces influencing how students are perceived in higher education - as customers instead of as learners or thinkers (Cook-Sather \& Felten, 2017; Neary \& Amsley, 2012; Wenstone, 2012). A recent study argued that SaP is a 'counternarrative that challenge[s] traditional and neoliberal views, creating space for relational narratives about learning, teaching, and higher education' (Matthews, Dwyer, Hines, \& Turner, 2018, p. 4). While SaP can represent many practices, it is fundamentally about relationships between teachers and learners underpinned by particular principles and values.

Drawing on three key guiding principles underlying partnership—respect, reciprocity, and shared responsibility (Cook-Sather et al., 2014) — Cook-Sather and Felten (2017, p. 181) assert that partnership is enacted within 'an ethic of reciprocity' (in contrast to a neoliberal ethic): a 'process of balanced give-and-take not of commodities but rather of contributions: perspectives, insights, forms of participation.' Healey et al. (2014, pp. 14-15) offer an extended list of values that guide partnership in practice: trust, courage, plurality, responsibility, authenticity, honesty, inclusivity, reciprocity, and empowerment. Importantly, $\mathrm{SaP}$ is aspirational with the language of partnership deliberately discussed as relational, 
egalitarian, and values-based to emphasise what is important about the ways we act-and seek to interact - when engaging in partnership praxis.

Given the rapid emergence of largely practitioner-based scholarship (MercerMapstone et al., 2017), analysis of various interpretive framings employed in SaP literature offers an opportunity for clarifying the relationship between theory and practice in scholarship on $\mathrm{SaP}$. Our intention is to reflect on and encourage the field as it matures from exploring and describing emerging practices to beginning to formulate theories of partnership praxis. As we explain in the next section, because the subject of this discussion is that process of maturation - the movement toward generating theories of partnership praxis - we focus in our analysis on the process of theorising.

\section{Presenting Theories versus Theorising in Higher Education}

Debates about what counts as a theory are complex. Indeed, Trowler (2012) argues that the role of theory is a wicked problem for higher education researchers. Trying to offer a simple definition of theory is problematic because how we define theory is grounded in our assumptions, which are inextricably entangled with our view of the world, our beliefs about research, and our understanding of knowledge. For example, Hammersley (2012) presents seven categories of distinct discourses on the meaning of theory. Thus, deciding whether or not a particular formulation 'counts' as a theory, and what that formulation aims to do, is not a straightforward process. We encountered this problem in SaP literature. As one example, communities of practice in higher education, evoked in the SaP literature we reviewed, has been referred to as both a theory and an idea (Tight, 2004). Hammersley (2012) suggests that scholars deal with the theory problem by explicitly communicating their stance on the intellectual function of theory. 
With that suggestion in mind, we situate our stance as theory in relation to practice because scholarship on engaging students as partners in teaching and learning is always about practice. However, rather than focus on whether or not the interpretive approaches to analysing practice used in $\mathrm{SaP}$ literature constitute theories per se, we chose to focus on theorising for the purposes of our analysis. Our close attention to the process of moving toward formulating theories of partnership praxis reflects where $\mathrm{SaP}$ is as an evolving field concerned with practice.

Therefore, we adapt Hutchings and Huber's (2008) argument in the emerging realm of the Scholarship of Teaching and Learning to suggest that theorising be understood as a process of tracing intellectual lineage, situating specific issues in a larger context, and bridging distinct disciplines to allow the adaptation of frameworks and findings from one field into new settings. Furthermore, we adopt Hammersley's (2012, p. 394) stance whereby theorising in relation to practice is an interpretive sense-making process that has 'the capacity to transform practice, either by providing a coherent underlying set of principles for understanding the world and guiding action within it, or through subverting conventional wisdom.' Our emphasis on process is consistent with the movement we seek to analyse: from loose and evolving theoretical foundations toward firmer theories.

\section{Rationale for the Usefulness of Three Forms of Theorising in SaP Scholarship}

If we focus on theorising as an active sense-making process moving toward formulating rather than presenting theories of partnership praxis, we suggest that it is appropriate to consider a wide range of interpretive processes. By linking the actions of 'building on,' 'drawing on, 'and 'imagining through' with particular terms - concepts, constructs, and metaphors, respectively—we aim to capture distinct but related sense-making processes, particular interpretive approaches that we see as generative forms of theorising. 
Concepts, constructs, and metaphors are abstract ideas rather than empirical entities, yet each powerfully affects both perception and action, and each can be used for a variety of purposes that are particularly important in supporting the further development of SaP work and in analysing that development. These terms can be used to situate, illuminate, or legitimise a practice, often borrowing from other areas of thought or practice. They can be used to identify, explain, or account for phenomena and how they are experienced. And finally, they can inform and guide thinking and action as an assertion of particular values or as a 'conscience' to remind us why we are taking a particular partnership approach. While they can either precede practice or emerge from it, and while they are all organising devices within which some phenomena are foregrounded or supported while others are eclipsed or obstructed, they are related but not synonymous terms.

Concepts are ideas, notions, or preliminary ways of naming newly emerging, existing, or possible phenomena. They represent 'a sort of cognitive grouping' (Spitzer, 1975, p. 36). The set of related ideas that form a concept is used to make sense and capture that sense in a term. Concepts are not only abstract but also tentative; the term is evoked to signal an as-yetnot-fully-defined phenomenon. For instance, Taylor and Bovill (2018, p. 112) 'develop the concept of ecology of participation' in order to advance 'current thinking on higher education curricula and partnership ethics' and to use a set of ideas from process philosophy 'to consider co-creation in the curriculum and co-creation of the curriculum.'

Constructs name phenomena that are always at play but that are unprovable and run the risk of being invisible. According to Swain (2007, p. 14), constructs are 'theoretical creations that are based on observations but which cannot be seen either directly or indirectly.' The term 'construct' not only highlights that the phenomenon is created, but also holds up that creation for critical analysis; it allows us to operationalise something abstract so that we can study it. Constructs in analyses of partnership, then, function as intentional 
naming of phenomena that might, on the one hand, be assumed to be 'natural,' while on the other hand defy the assumption of being 'provable.' Gender, identity, and power are all constructs used to analyse partnership, and indeed, partnership itself is a construct.

Metaphors assert that one thing is another, equating two things that are not literally the same to expand or deepen understanding. For instance, a student is a producer. Metaphors such as this use of the language of 'seeing through' (Black, 1962, p. 41) or 'seeing-as'—a language that highlights the space between two things — rather than the language of 'describing' (Schön, 1979, p. 259)—a language that focuses just on one thing. Therefore, thinking about a student as a producer prompts one to rethink both terms, catalysing a 'break with the taken-for-granted' (Greene, 2000, p. 5). As this and numerous other examples illustrate, through their juxtaposition of seemingly unlike things, metaphors provide us with 'new perspectives' (Turner, 1974, p. 31) that prompt us to re-see our roles, relationships, and work in teaching and learning.

How conscious and intentional we are about the interpretive framing in which we engage affects not only how $\mathrm{SaP}$ work is enacted but also how it is perceived and received. When readers can situate SaP within a familiar form of interpretive framing, that SaP work may be more comprehensible as a result of that familiarity. On the other hand, when the work is situated within a surprising form of interpretive framing, such as an unexpected metaphor, it may catalyse a new set of insights. In both cases, SaP can gain legitimacy by association, whether through reassurance or productive disruption, and the range of ways SaP is situated through interpretive framing contributes to the movement toward theories of pedagogical partnership praxis. 


\section{Methods}

We drew on the findings of a review of empirical SaP studies published in English from 2011 to 2015 that explicitly employed the language of $\mathrm{SaP}$ - or associated terms sharing a similar intention (e.g. student-staff partnerships, students as co-creators) - in the context of higher education (Mercer-Mapstone et al., 2017). We then expanded our review to include nonempirical studies (e.g. editorials, opinion pieces, conceptual works that did not collect primary data) and articles published prior to 2011 or following 2015 with which we were familiar, including works cited in a keynote and subsequent essay on theory in the scholarship on student-staff partnerships (Cook-Sather, 2018).

We re-read and re-analysed the identified publications first to identify explicitly stated interpretive framings, and we made a subjective determination as to whether scholars intentionally employed the interpretive framing in a way that drew on existing literatures and applied the interpretive framing to SaP throughout the paper. For example, we found many publications that mentioned the term power in relation to SaP practice but did not elaborate on the construct of power through reference to literature or as an interpretive framing underpinning the work. We then summarised arguments, noting salient quotes, and categorised them. We used a thematic analysis approach (Braun \& Clarke, 2006) with iterative cycles of clustering, rearranging, and classifying, followed by a process of defining and describing. This resulted in three tables with descriptions and illustrative quotes from relevant publications (Matthews, Cook-Sather, Acai, Dvorakova, Felten, Marquis, \& MercerMapstone, 2018).

Our choices in the review process of what to include necessarily shaped our findings regarding which interpretive framings are in use in the literature. What we present, then, is a conceptual review of selected publications, including some of our own published works, that 
reflect how a range of scholars theorise partnership practices in SaP literature - a sampling intended to invite further dialogue and exploration rather than to offer a complete mapping.

\section{Interpretive Framing in Scholarship of Students as Partners}

Our analysis suggests that the framing many scholars use in theorising SaP reflects a sociocultural paradigm: The three kinds of interpretive framing we found tended to be informed by a view of the world that is subjective-where reality is created, there is more than a single truth, and the relationship between individuals and their environment is inseparable. In other words, our findings affirm that partnership is a complex, context-specific practice that is ultimately relational (Bovill, 2017; Bryson, Furlonger, \& Rinaldo-Langridge, 2016; Cook-Sather \& Felten, 2017; Healey \& Healey, 2018; Matthews, 2017). Displayed in Figure 1 are the three overlapping forms of interpretive framing evoked in scholarship of SaP.

[Figure 1 near here]

For each of the three kinds of interpretive framing we offer a summary of the concepts, constructs, and metaphors that guide interpretation of pedagogical partnership in $\mathrm{SaP}$ scholarship. Our intention is not to critique or evaluate each publication or interpretive framing, but rather to demonstrate how each was used in relationship to SaP.

\section{Building on Concepts}

Our review identified a range of interpretive framing approaches in SaP scholarship that build on concepts that have been discussed in existing literature: threshold concepts, liminality, participative reality, communities of practice, student engagement, deliberative democracy, and ecology of participation.

The notion of threshold concepts proposes that there are 'conceptual gateways' or 'portals' that, once passed through, lead to 'a transformed internal view of subject matter, 
subject landscape, or even world view' (Meyer \& Land, 2006, p. 19). Marquis et al. (2016, p. 6) explain that 'passing through the partnership threshold entails coming to understand staff and students as collegial contributors to teaching and learning, with complementary roles, responsibilities, and perspectives, and realising this understanding within actual teaching and learning practices' (see also Cook-Sather, 2014a; Cook-Sather \& Luz, 2015; Felten, 2013; Werder, Thibou, \& Kaufer, 2012).

Liminality refers to 'a realm of pure possibility whence novel configurations of ideas and relations may arise' (Turner, 1995, p. 97), and where participants are 'ambiguous, neither here nor there, betwixt and between all fixed points of classification' (Turner, 1974, p. 232). Arguing for the radical transformation that can come about when people are positioned within liminal spaces, Cook-Sather and Felten (2017) examine the role of liminality within academic leadership as partnership, while Cook-Sather and Alter (2011) focus on the liminal role of student partners in classroom-based, student-staff pedagogical partnerships (also see Jensen \& Bennett, 2016; Matthews et al., 2018).

Participative reality 'views human beings as equal participants in the world, who cocreate a reality which is shaped by the nature and quality of our subjective-objective relationships' (Walton, 2013, p. 402). It is evoked to discuss the challenges and benefits of co-constructing learning opportunities. The concept of communities of practice refers to people engaging in a collective learning process in a shared domain of a human endeavour (Wenger \& Wenger-Trayner, 2015). Members of a community of practice 'develop a shared repertoire of resources: experiences, stories, tools, ways of addressing recurring problems' that illustrate how a student and staff member can simultaneously be constrained and enabled in a shared partnership project (Meacham, Castor, \& Felten, 2013, p. 2; see also Tierney, 2012). 
Student engagement - a commonly discussed yet highly contested concept in higher education policy and practice - is evoked in relation to partnership in various ways. Bovill, Cook-Sather, Felten, Millard, and Moore-Cherry (2016) situated student engagement, partnership, and co-creation as in dynamic interaction with one another. Shifting that dynamic, Bovill and Felten (2016), Bryson (2014), Millard, Bartholomew, Brand and Nygaard (2013), and Taylor, Wilding, Mockridge and Lambert (2012) argue that partnership is a path toward student engagement. Widening the focus regarding who is engaged, CookSather (2013) argues for thinking about staff/faculty engagement as well as student engagement within partnership. Finally, Matthews (2016) makes an argument for redefining student engagement as partnership.

The principles of deliberative democracy offer 'an ideal method of engaging students in the curriculum renewal process' that is particularly well suited to developing student graduate attributes such as leadership within the ethos of SaP (Bell, Carson, \& Piggot, 2013, p. 502). And finally, Taylor and Bovill (2017) use the concept of an ecology of participation to analyse co-created curricula. Their goal is to illuminate the many ways that students and staff can engage as partners in creating curricula, offering an expansive conception of SaP.

Each of these interpretive framings aims to 'shake us out of the complacency of seeing/hearing/thinking as we always have, or might have, or will have' (Jackson \& Mazzei, 2013, p. 269). They illustrate how interpretive framing that builds on concepts from a wide range of literatures has the effect of positioning SaP in relation to already established concepts developed within various disciplines. This analytical approach can be grounding, situating, or disruptive.

\section{Drawing on Constructs}


Constructs capture and hold up for analysis seemingly natural and everyday, yet invisible or contested, phenomena. Constructs can be understood as constituting variables within partnership and lived experiences of partnership, as well as interpretive framings for analysing partnership. Identity, power, and gender are constructs explicitly evoked in SaP work.

In an analysis of how a pedagogical partnership program supported dialogue between students and faculty with varying positions, perspectives, and racial or cultural identities, Cook-Sather (2015, p. 2) defines identity as the way in which 'individuals define and experience themselves and are defined by others - how an individual/personal sense of sociocultural location and character intersects with how that individual is constructed in many different ways within any given culture and society.' In the context of participatory research on diversity, Gibson et al. (2017) highlight how engaging students as both participants and co-researchers served to blur identities in ways that seemed at first disruptive and problematic but ultimately proved liberating. Reflecting on their experiences in SaP, Mercer-Mapstone, Marquis, and McConnell (2018) discuss a partnership identity that formed when they crossed the partnership threshold.

Power shapes how partnership is approached, enacted, and considered. In a discussion of a partnership approach to course redesign, Mihans, Long, and Felten (2008) describe the challenges and inspirations of the process. They conclude: 'By working together to take full advantage of all of the team's expertise, we began to understand the true meaning and importance of shared power through collaboration' (Mihans, Long, \& Felten, 2008, p. 5). This quiet statement of revolution is amplified in later discussions of power in partnership. For instance, Crawford (2012, p. 57) argues: 'It is not enough to recognise the inequality in power that characterises the relationship between student and teacher; that recognition must be a catalyst that challenges and enables cultural transformation.' Similarly, Seale et al. (2015) 
suggest that 'ownership and expertise' are two key aspects of power in partnerships. Taking another angle, Matthews (2017) invokes Bourdieu's theory of habitus and capital to reframe expertise as a form of power typically possessed by academics that $\mathrm{SaP}$ affords to students.

Considering partnership in relation to gender, Mercer-Mapstone and Mercer (2018) view SaP through a feminist lens to illuminate a shared ethos of radical empowerment. Linking the construct of gender to the construct of power, they argue that $\mathrm{SaP}$ and feminism 'seem to be seated in similar and radical processes of challenging, questioning, destabilising, deconstructing, and empowering' (Mercer-Mapstone \& Mercer, 2018, p. 6).

Drawing on constructs is a way to name a phenomenon and create a space within which that phenomenon might play out differently. Although they 'cannot be seen either directly or indirectly' (Swain, 2007, p. 14), constructs nevertheless have particular power to inform perception and action. Revealing can lead to revising.

\section{Imagining through Metaphors}

In asserting that one thing is another when it clearly is not, metaphors are often startling or even confusing at first glance because of the apparent differences between the terms they compare. They do much of their work at the unconscious level by accessing and revealing assumptions about the nature of things, and they can catalyse emotional as well as intellectual reframing. Our review found that metaphors appearing in SaP publications include selfauthorship, student as producer, translation, and student voice.

Authoring is typically thought of as something one does with a text, so applying it to the 'self' evokes a set of associations to do with composing, revising, and, perhaps, (re)presenting. Baxter-Magolda (2007, p. 69) suggests that self-authoring is 'the internal capacity to define one's own belief system, identity, and relationships.' So, if engaging in partnership is self-authorship, it is a process of each participant in partnership creating herself. 
Student as producer explicitly uses the metaphorical language of 'seeing through' (Black, 1962, p. 41) or 'seeing-as' to call for a 'break with the taken-for-granted' (Greene, 2000, p. 5), which in this case, is the positioning of students as consumers. Arguing that students are producers 'is a critical response to attempts by recent governments in the UK, and around the world, to create a consumerist culture among undergraduate students' (Neary, 2010).

Translation, like self-authorship, equates the application of a set of typically linguistic terms and processes with the human experience of transformation. While a self cannot literally be translated, the metaphor 'is an evocative combination of communicative and experienced change' that powerfully highlights 'transformations of language and sense of self’ (Cook-Sather \& Abbot, 2016, p. 2; see also Gibson et al., 2017).

Student voice signals the actual sound of students' voices as they inform conversations about educational practice, and also serves as a metaphor for students' power and participation in those conversations (Cook-Sather, 2006; Werder \& Otis, 2010). It asserts that voice is power and participation. Frison and Melacarne (2017) discuss the danger that student voice can be restricted and formulated in such a way as to reduce the chance of power sharing. By imagining through the metaphor of student voice, Brooman, Darwent, and Pimor (2015) argue that their SaP practice improved curriculum, and Cook-Sather (2014b) documents profound changes in the perspectives of both students and faculty who engage in pedagogical partnership.

Part of what makes metaphors powerful is the way they operate both abstractly and actually. While partners do not literally author (write) themselves and voice is not literally power and presence, the equation of the unlike terms makes the reality suggested by the abstraction more imaginable. 


\section{Discussion}

Our analysis reveals ways in which $\mathrm{SaP}$ is characterised by highly complex relationships and phenomena that take multiple forms and have, as yet, no definite or firm language to name these experiences - certainly no 'grand theory of SaP' has emerged. The interpretive framing in which scholars of SaP engage seeks to illuminate the human and relational aspects of $\mathrm{SaP}$ that, while always context dependent (Healey \& Healey, 2018), unfold within the powerladen social structures that characterise universities. The interpretive processes captured by building on concepts, drawing on constructs, and imagining through metaphors enact approaches to theorising from a sociocultural worldview where learning is subjective, social, and intertwined with how we see ourselves as individuals, in relation to others, and in the world.

The complexity of theorising in and on SaP is evident in the ways that many of the approaches to framing overlap, inform one another, and endeavour to explain how students and staff engage in partnership in diverse contexts. For example, because the construct of identity underpins the concept of communities of practice, Tierney $(2012$, p. 9) reflects on how participating within a community of practice of students and staff 'has consequences on the identity of participants outside the experience of that community.' As another example, Seale et al. (2015, p. 550) illustrate the way several of the concepts, constructs, and metaphors we have highlighted in this discussion are inextricably intertwined: 'If we ... ignore issues of power and resistance, we will fall far short of the vision of student engagement and the ideals of strong participation and expression of student voice.'

At a 'meta' level in relation to this discussion, students as partners is itself a complex intersection of concepts, constructs, and metaphor. Matthews (2017) has suggested that students as partners is a metaphor; using the language of 'seeing-as,' it asserts that students are partners, thereby juxtaposing two terms not often linked to imagine a very different way 
of conceptualising the role of student in higher education. SaP draws on particular concepts, often expressed as principles, striving to name an alternative to and change a phenomenon (student-educator relationships) that seems natural but is actually created. Challenging traditional assumptions about the role of 'students' and 'teachers' in higher education (Bryson et al., 2016; Cook-Sather et al., 2014; Healey et al., 2014; Matthews, 2017), SaP is identity work that seeks to disrupt taken-for-granted power structures in universities. Many, though not all, of the interpretative frames brought to bear on partnership practice speak to the idea of $\mathrm{SaP}$ as a complex sociocultural phenomenon that is a radically transformative yet risky praxis.

Importantly, we acknowledge that theorising on SaP practice is unfolding in a broader political landscape increasingly shaped by neoliberal ideologies, as several scholars have argued (Cook-Sather \& Felten, 2017; Neary, 2010; Neary \& Amsley, 2012; Matthews, 2017; Matthews, Dwyer, Russell, \& Enright, 2018). Moving forward, we advocate developing theories of partnership praxis that hold firm commitments to social justice, and that challenge and transcend neoliberal political discourse influencing the sociocultural context of higher education in which $\mathrm{SaP}$ is practiced. As some scholars are evoking SaP practices as radical praxis to challenge the status quo, critical theories as interpretative framings for scholarship on partnership could further efforts to make sense of SaP as transformative work, as Bovill

\section{(2013) has suggested.}

Rather than lament the lack of theory governing SaP work, we are inspired by the multiple, diverse ways scholars engage in interpretive framing of SaP practice because they embrace the multiplicity and boundary crossing that are consistent with the principles and values of partnership practice. Thus, theorising in SaP literature speaks to Trowler's (2012, p. 277) notion of the use of theory 'in the imaginarium' where theorising is 'creative and emancipatory.' In this approach, 'the relationship between theory and the world is turned on its head: theory does not explain the world, rather the world is constructed and reconstructed 
through theory.' Our emphasis on theorising as a process is intended to make space for and support the process of evolution in which $\mathrm{SaP}$ is engaged and the movement toward formulating theories of partnership praxis that such evolution traces.

\section{Conclusion}

In this article we explored an array of interpretive framings that scholars bring to bear on SaP. In so doing, we celebrate the expansive and creative theorising currently unfolding in SaP scholarship take seriously the disruptive ethos and messy human relational processes of partnership. Like Ball (1995, pp. 265-266), we advocate the pursuit of theory that is 'a vehicle for thinking otherwise, ' that is, 'a platform for outrageous hypotheses and for unleashing criticism' that seeks to 'de-familiarise present practices and categories, to make them seem less self-evident and necessary, and to open up spaces for the invention of new forms of experience'. We encourage further diversity in the development and use of interpretive frames in scholarship of $\mathrm{SaP}$ - theorising that delves deeply into the complex partnership processes that always involve power and identity. Our analysis continues the conversations amongst scholars and practitioners in this emerging field that we hope moves us toward formulating theories of partnership praxis.

\section{Acknowledgements}

We are grateful to Sophia Abbot, Christine Black, Breagh Cheng, Mick Healey, Ruth Healey, Gali Katznelson, Sabrina Kirby, Kris Knorr, Alex Lerczak, Mythili Nair, Rafaella Shammas, Kelly Swaim, and Jarred Turner for their partnership in this work. 


\section{References}

Ball, S.J. (1995). Intellectuals or technicians? The urgent role of theory in educational studies. British Journal of Educational Studies, 43(3), 255-271.

Baxter Magolda, M. B. (2007). Self-authorship: The foundation for twenty-first-century education. New Directions for Teaching and Learning, 2007(109), 69-83.

Bell, A., Carson, L., Piggott, L. (2013). Deliberative democracy for curriculum renewal. In E. Dunne, D. Owen (Eds.), The student engagement handbook: Practice in higher education (pp. 499-508). Bingley, UK: Emerald.

Black, M. (1962). Models and metaphor: Studies in language and philosophy. Ithaca, NY: Cornell University Press.

Bovill, C. (2013). Students and staff co-creating curricula - a new trend or an old idea we never got around to implementing? In C. Rust (Ed.), Improving learning through research and scholarship: 20 years of ISL (pp. 96-108). Oxford, UK: The Oxford Centre for Staff and Educational Development.

Bovill, C. (2017). A framework to explore roles within student-staff partnerships in higher education: Which students are partners, when, and in what ways? International Journal for Students as Partners, 1(1), 1-5.

Bovill, C., Cook-Sather, A., Felten, P., Millard, L., \& Moore-Cherry, N. (2016). Addressing potential challenges in co-creating learning and teaching: Overcoming resistance, navigating institutional norms and ensuring inclusivity in student-staff partnerships. Higher Education, 71(2), 195-208.

Bovill, C., \& Felten, P. (2016). Cultivating student-staff partnerships through research and practice. International Journal for Academic Development, 20(1), 1-3.

Braun, V., \& Clarke, V. (2006). Using thematic analysis in psychology. Qualitative Research in Psychology, 3(2), 77-101. 
Brooman, S., Darwent, S., \& Pimor, A. (2015). The student voice in higher education curriculum design: Is there value in listening? Innovations in Education and Teaching International, 52(6), 663-674.

Bryson, C. (Ed.). (2014). Understanding and developing student engagement. London, UK: Routledge.

Bryson, C., Furlonger, R., \& Rinaldo-Langridge, F. (2016). A critical consideration of, and research agenda for, the approach of "students as partners." In Proceedings of 40th International Conference on Improving University Teaching, Faculty of Law, University of Ljubljana, Ljubljana, Slovenia, 15-17 July 2015. Retrieved from: http://www.iutconference.com/2016/01/a-critical-consideration-of-and-researchagendafor-the-approach-of-students-as-partners/

Cook-Sather, A. (2006). Sound, presence, and power: "Student voice" in educational research and reform. Curriculum Inquiry, 36(4), 359-390.

Cook-Sather, A. (2013). Catalyzing multiple forms of engagement through student-faculty partnerships exploring teaching and learning. In E. Dunne, D. Owen (Eds.), The student engagement handbook: Practice in higher education (pp. 549-565). Bingley, UK: Emerald.

Cook-Sather, A. (2014a). Student-faculty partnership in explorations of pedagogical practice: A threshold concept in academic development. International Journal for Academic Development, 19(3), 186-198.

Cook-Sather, A. (2014b). Multiplying perspectives and improving practice: What can happen when undergraduate students collaborate with college faculty to explore teaching and learning. Instructional Science, 42(1), 31-46. 
Cook-Sather, A. (2015). Dialogue across differences of position, perspective, and identity: Reflective practice in/on a student-faculty pedagogical partnership program. Teachers College Record, 117 (2).

Cook-Sather, A. (2018). What our uses of theory tell us about how we conceptualize studentstaff partnership. Student Engagement in Higher Education Journal, 2(1), 101-105. https://journals.gre.ac.uk/index.php/raise/article/view/Bryson/646

Cook-Sather, A. (in press). Tracing the evolution of student voice in educational research. In R. Bourke \& J. Loveridge (Eds.) Radical collegiality' through student voice. Springer Publishers.

Cook-Sather, A., \& Abbot, S. (2016). Translating partnerships: How faculty-student collaboration in explorations of teaching and learning can transform perceptions, terms, and selves. Teaching \& Learning Inquiry, 4(2), 1-14.

Cook-Sather, A., \& Alter, Z. (2011). What is and what can be: How a liminal position can change learning and teaching in higher education. Anthropology \& Education Quarterly, 42(1), 37-53.

Cook-Sather, A., Bovill, C., \& Felten, P. (2014). Engaging students as partners in learning and teaching: A guide for faculty. San Francisco, CA: Jossey-Bass.

Cook-Sather, A., \& Felten, P. (2017). Ethics of academic leadership: Guiding learning and teaching. In F. Su, \& M. Wood (Eds.), Cosmopolitan perspectives on academic leadership in higher education (pp. 175-191). London, UK: Bloomsbury.

Cook-Sather, A., \& Luz, A. (2015). Greater engagement in and responsibility for learning: What happens when students cross the threshold of student-faculty partnership. Higher Education Research \& Development, 34(6), 1097-1109.

Crawford, K. (2012). Rethinking the student/teacher nexus: Students as consultants on teaching in higher education. In M. Neary, L. Bell \& H. Stevenson (Eds.), Towards 
teaching in public: Reshaping the modern university (pp. 52-67). London, UK: Bloomsbury.

Felten, P. (2013). Introduction: Crossing thresholds together. Teaching and Learning Together in Higher Education, 9. Retrieved from http://repository.brynmawr.edu/cgi/viewcontent.cgi? article $=1062 \&$ context $=$ tlthe

Frison, D., \& Melacarne, C. (2017). Introduction - Students-faculty partnership in Italy: Approaches, practices, and perspectives. Teaching and Learning Together in Higher Education, 20. Retrieved from http://repository.brynmawr.edu/tlthe/vol1/iss20/1/

Gibson, S., Baskerville, D., Berry, A., Black, A., Norris, K., \& Symeonidou, S. (2017). Including students as co-enquirers: Matters of identity, agency, language and labelling in an international participatory research study. International Journal of Educational Research, 81, 108-118.

Greene, M. (2000). In search of metaphor. Paper presented at the Annual Meeting of the American Educational Research Association, New Orleans, United States.

Hammersley, M. (2012). Troubling theory in case study research. Higher Education Research \& Development, 31(3), 393-405.

Healey, M., Flint, A., \& Harrington, K. (2014). Students as partners in learning and teaching in higher education. York, UK: Higher Education Academy.

Healey, M., \& Healey, R. (2018). 'It depends': Exploring the context-dependent nature of students as partners practices and policies. International Journal for Students as Partners, 2(1).

Hutchings, P., \& Huber, M. T. (2008). Placing theory in the Scholarship of Teaching and Learning. Arts \& Humanities in Higher Education, 7(3), 229-244.

Jackson, A. Y., \& Mazzei, L. A. (2013). Plugging one text into another: Thinking with theory in qualitative research. Qualitative Inquiry, 19(4), 261-271. 
Jensen, K., \& Bennett, L. (2016). Enhancing teaching and learning through dialogue: A student and staff partnership model. International Journal for Academic Development, 21(1), 41-53.

Marquis, E., Puri, V., Wan, S., Ahmad, A., Goff, L., Knorr, K., Vassileva, I., \& Woo, J. (2016). Navigating the threshold of student-staff partnerships: A case study from an Ontario teaching and learning institute. International Journal for Academic Development, 21(1), 4-15.

Matthews, K. E. (2016). Students as partners as the future of student engagement. Student Engagement in Higher Education Journal 1(1), 1-5.

Matthews, K. E. (2017). Five propositions for genuine students as partners practice. International Journal of Students as Partners, 1(2), 1-9.

Matthews, K. E, Cook-Sather, A., \& Healey, M. (2018). Connecting learning, teaching, and research through student-staff partnerships: Toward universities as egalitarian learning communities. In V. Tong, A. Standen, A., \& M. Sotiriou, (Eds.), Shaping higher education with students: Ways to connect research and teaching. London, UK: University College of London Press.

Matthews, K. E., Cook-Sather, A., Acai, A., Dvorakova, S. L., Felten, P., Marquis, E., \& Mercer-Mapstone, L. (2018). An analysis of interpretive framing in literature on students as partners in teaching and learning: Data tables. University of Queensland. Data Collection. https://doi.org/10.14264/uql.2018.519

Matthews, K.E., Dwyer, A., Hines, L., \& Turner, J. (2018). Conceptions of students as partners. Higher Education, 1-15.

Matthews, K. E., Dwyer, A., Russell, S., \& Enright, E. (2018). It is a complicated thing: leaders' conceptions of students as partners in the neoliberal university. Studies in Higher Education, 1-12. 
Meacham, M., Castor, M., \& Felten, P. (2013). Partners as newcomers: Mixed-role partnerships as Communities of practice. Teaching and Learning Together in Higher Education, 10. Retrieved from http://repository.brynmawr.edu/tlthe/vol1/iss10/5/ Mercer-Mapstone, L., Dvorakova, L.S., Matthews, K.E., Abbot, S., Cheng, B., Felten, P., Knorr, K., Marquis, E., Shammas, R., \& Swaim, K. (2017). A systematic literature review of students as partners in higher education. International Journal of Students as Partners, 1(1), 1-23.

Mercer-Mapstone, L., Marquis, E., \& McConnell, C. (2018). The 'partnership identity' in higher education: Moving from 'us' and 'them' to 'we' in student-staff partnership. Student Engagement in Higher Education Journal, 2(1).

Mercer-Mapstone, L., \& Mercer, G. (2018). A dialogue between partnership and feminism: Deconstructing power and exclusion in higher education. Teaching in Higher Education, 23(1), 137-143.

Meyer, J., \& Land, R. (2006). Overcoming barriers to student understanding: Threshold concepts and troublesome knowledge. London, UK: Routledge.

Mihans, R., Long, D., \& Felten, P. (2008). Power and expertise: Student-faculty collaboration in course design and the scholarship of teaching and learning. International Journal for the Scholarship of Teaching and Learning 2(2).

Millard, L., Bartholomew, P., Brand, S., \& Nygaard, C. (2013). Why student engagement matters. In C. Nysgaard, S. Brand, P. Bartholomew \& L. Millard (Eds.), Student engagement: Identity, motivation and community (pp. 1-15). Farringdon, UK: Libri.

Neary, M. (2010). Student as producer: A pedagogy for the avant-garde? Learning Exchange, 1(1). Retrieved from http://eprints.lincoln.ac.uk/4186/

Neary, M., \& Amsley, S. (2012). Occupy: A new pedagogy of space and time? Journal of Critical Education Policy, 10(2), 106-138. 
Peters, J. (2016). The pedagogy of partnership: Six principles for action. Educational Developments, 17(4), 8-9.

Schön, D. A. (1979). Generative metaphor: A perspective on problem-setting in social policy. In A. Ortony (Ed.), Metaphor and thought (pp. 254-83). Cambridge, UK: Cambridge University Press.

Seale, J., Gibson, S., Haynes, J., \& Potter, A. (2015). Power and resistance: Reflections on the rhetoric and reality of using participatory methods to promote student voice and engagement in higher education. Journal of Further and Higher Education, 39(4), 534552.

Spitzer, D. R. (1975). What is a concept? Educational Technology, 15(7), 36-39.

Swain, E. (2007). Constructing an effective 'voice' in academic discussion writing: An appraisal theory perspective. In A. McCabe, M. O’Donnell \& R. Whittaker (Eds.), Advances in language and education (pp. 166-184). New York, NY: Bloomsbury.

Taylor, C., \& Bovill, C. (2018). Towards an ecology of participation: Process philosophy and co-creation of higher education curricula. European Educational Research Journal, $17(1), 112-128$.

Taylor, P., Wilding, D., Mockridge, A., \& Lambert, C. (2012). Reinventing engagement. In I. Solomonides, A. Reid \& P. Petocz (Eds.), Engaging with learning in higher education (pp. 259-278). Farringdon, UK: Libri.

Tierney, A. M. (2012). Undergraduate interns as staff developers: Flowers in the desert. Innovations in Education and Teaching International, 49(1), 7-17.

Tight, M. (2004). Research into higher education: An a-theoretical community of practice? Higher Education Research \& Development, 23(4), 395-411.

Trowler, P. (2012). Wicked issues in situating theory in close-up research. Higher Education Research \& Development, 31(3), 273-284. 
Turner (1995 [1969]). Liminality and communitas. In The ritual process: Structure and antistructure (pp. 94-130). New York, NY: Walter de Gruyter.

Turner, V. (Ed). (1974). Dramas, fields, and metaphors: Symbolic action in human society. Ithaca, NY: Cornell University Press.

Walton, J. (2013). Active participation in learning: Students creating their educational experience. In E. Dunne, D. Owen (Eds.), The student engagement handbook: Practice in higher education (pp. 401-419). Bingley, UK: Emerald.

Wenger, E. \& Wenger-Trayner, B. (2015). Communities of practice a brief introduction. Retrieved from http://wenger-trayner.com/wp-content/uploads/2015/04/07-Briefintroduction-to-communities-of-practice.pdf

Wenstone, R. (2012). NUS-A Manifesto for partnership. Retrieved from http://www.nusconnect.org.uk/resourcehandler/0a02e2e5-197e-4bd3-b7ede8ceff3dc0e4/

Werder, C., \& Otis, M. (Eds.) (2010). Engaging student voices in the study of teaching and learning. Sterling, VA: Stylus.

Werder, C., Thibou, S., \& Kaufer, B. (2012). Students as co-inquirers: A requisite threshold concept in educational development? The Journal of Faculty Development, 26(3), 3438. 
Figure 1: Interpretive framing in scholarship on students as partners. 